\title{
Radiogenomics of Renal Cell Carcinoma: Our Clinical Experience
}

YU.O. MYTSYK, Y.B. BORYS, V.E. DOSENKO, I.V. DATZ, Y.P. DIYCHUK, V.V. KOWALSKYY, S.M. PASICHNYK, V.M. MATSKEVYCH Danylo Halytskyi Lviv National Medical University, Lviv, Ukraine

$$
\text { E-mail: mytsyk.yulian@i.ua }
$$

Renal cell carcinoma (RCC) is relatively common pathology that is found roughly in $3 \%$ of all cases of malignant neoplasia in adults and approximately in $90 \%$ of malignant tumors arising because of a kidney [10]. Associations

() Mytsyk Yu.O., Borys Y.B., Dosenko V.E. et al., 2017 
between imaging features and genomic landscape of RCC have been recently investigated in order to characterize better tumor, diagnosting more precisely, staging and establishing more accurate prognosis comparing to classic histopathologic approach. Such integration of imaging and molecular biomarkers has led to novel concept of "radiogenomics" or "radiogenetics" [4, 5, 7]. A great number of investigators have assessed a role of certain microRNAs (miR) in context of RCC radiogenomics, however the quantity of such works is quite small $[3,4,9]$.

In our previous work we have already described usefulness of expression of mi-R-15a measured in urine during RCC diagnostics [1]. Moreover, high miR-15a expression values have been significantly associated with poor survival rates in patients with RCC [2].

The purpose. The goal of the study is investigation of associations between cross-sectional imaging features of RCC and urine expression levels of miR-15a.

Materials and methods. Conducting of the research has been approved by Ethical Committee of Danylo Halytsky Lviv National Medical University, Ukraine (protocol № 5, 05.25.2015), and has been carried out in accordance with ethical standards formulated in the Declaration of Helsinki 1975. Our study has been conducted at Urology Department of this institution and at General and Molecular Pathophysiology Department of Bogomoletz Institute of Physiology of National Academy of Sciences of Ukraine during 2015-2017 years.

52 adult patients with RCC according to clinical and imaging data have been engaged in the study. The size of the tumors have ranged from 2,08 to $12,7 \mathrm{sm}$ and average size of $7,01 \pm 2,08 \mathrm{~cm}$. Percutaneous kidney biopsy or previous kidney tumor treatment has been performed in all patients. In all patients' multiphase CT or MRI imaging with contrast enhancement has been performed prior to surgical treatment using standard abdominal protocols [6]. In all cases urine collecting and miR-15a expression measuring has been performed according to earlier described method, using quantitative polymerase chain reaction [1]. Associations between miR-15a expression and such RCC imaging features as necrosis, renal vein invasion, presence of intratumoral calcifications, definition of tumor margin and architecture, presence of collecting system invasion, intratumoral hypervascularity, homogeneous or nodular tumor enhancement pattern on nephrographic phase images have been assessed. All patients have been treated surgically with following pathologic analysis.

Microsoft Excel 2016 and SPSS v.22 software packages have been used for the statistical data processing.

Results and discussion. RCC cases have been classified concordantly to 7th edition of AJCC cancer staging manual: T1aN0M0 ( $\mathrm{n}=13,25,0 \%)$, T1bN0M0 ( $\mathrm{n}=15,28,85 \%)$, T2aN0M0 ( $\mathrm{n}=12,23,08 \%)$, T2bN0M0 ( $=5$, $9,62 \%)$, T3aN0M0 ( $=4,7,69 \%)$, T3aN1M0 $(\mathrm{n}=3,5,77 \%)$. Based on pathologic analysis all RCCs have been classified according to histologic subtypes - clear cell RCC $(\mathrm{n}=22)$, papillary RCC $(\mathrm{n}=16)$, chromophobe RCC $(n=14)$. Simplified two-tiered Fuhrman grading system has been used, in which grades I and II (low grade, $\mathrm{n}=12$ ) and grades III and IV (high grade, $\mathrm{n}=10$ ) have been combined for the clear cell RCC grading.

As a result of our investigation we have found significant evidences of associations between miR-15a expression levels and RCC imaging features. The expression values of miR-15a in urine of patients with RCC have varied from 91,35 to 5,52 relative fluorescence units (RFU), average has been $-54,58 \pm 37,76$ RFU. High expression levels of miR-15a (> $25 \mathrm{RFU}$ ) in patients with RCC have been common in presence of such tumor imaging features as necrosis $(p<0,05)$, ill-defined margins of the lesion $(\mathrm{p}<0,05)$ and intratumoral hypervascularity $(p<0,01)$. Lower miR-15a expression levels $(<25 \mathrm{RFU})$ have been associated with imaging evidence of renal vein $(p<0,05)$ and collecting system $(p<0,05)$ invasion, nodular tumor enhancement pattern on nephrographic phase images $(p<0,05)$ and multicystic tumor architecture $(p<0,05)$. However, there has 
not been significant association between miR-15a expression and presence of intratumoral calcifications on cross-sectional images $(p>0,05)$. The mean values of miR-15a expression for each of RCC imaging characteristics as well their frequency are presented on figure 1.

Conclusions. Radiogenomic analysis may provide valuable information for predicting of miR-15a expression levels in urine of patients with RCC. In clinical conditions under which there is no possibility to perform genetic assay, imaging features of RCC can be used as surrogates of miR-15a expression to perform prognostication of disease biologic behavior.

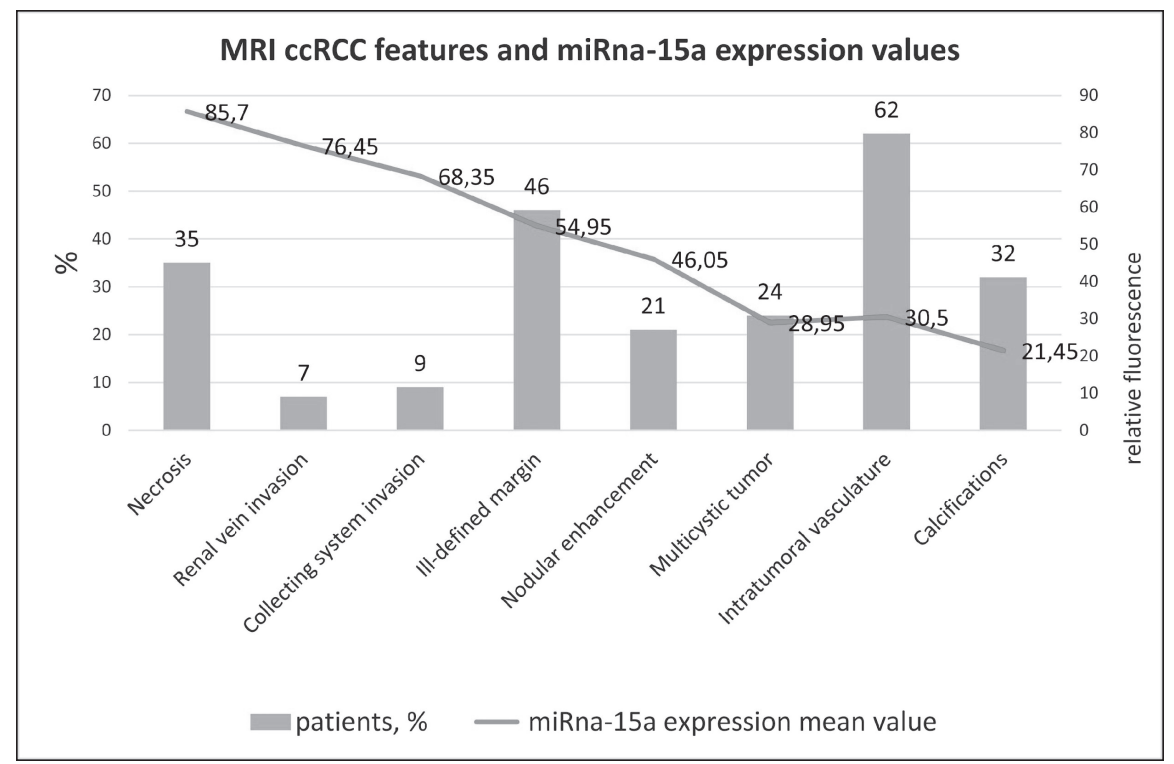

Figure 1. Associations between RCC imaging features and mean miR-15 expression levels in urine

\section{REFERENCES}

1. Мицик ЮО, Досенко ВС, Борис ЮБ, Даи IВ, Ільчишин ОС, Чернова НВ та ін. Можливість застосування мікроРНК-15a, визначеної у сечі, для діагностики нирковоклітинного раку, Експериментальна та клінічна фрізіологія і біохімія. 2017;77(1):49-53. (Mytsyk Yu, Dosenko V, Borys Yu, Ilchyshyn O, Chernova N, Dats I, et al. The Possibility of Application of Detected in Urine microRNA-15a for Diagnostics of Renal Cell Carcinoma. Experimental and Clinical Physiology and Biochemistry. 2017;77(1):49-53. https: / /doi.org/10.25040/ecpb2017.01.049). 2. Мицик ЮО, Досенко ВС, Борис ЮБ, Іллюк ПО, Максилович I, Чернова НВ. Застосування експресії мікроРНК-15а, визначеної у тканинах пухлини у якості прогностичного біомаркеру нирково-клітинного раку. Урологія. - 2017;21(3):39-48 (Mytsyk Yu, Dosenko V, Borys Yu, Illiuk $P$, Maksymovych I, Chernova N. Application of MicroRNA-15a Measured in Tumor Tissues as a Prognostic Biomarker of the Renal Cell Carcinoma. Urology. 2017;21(3):39-48). 3. Badia S, Bellini D, Rengo M, Caruso D, Picchia S, Laghi A, Latina I. CT Texture Analysis of Clear Cell Renal Carcinoma (ccRCC) in a Radiogenomics Prospective - a Pilot Study. European Congress of Radiology. 2017; Poster No.: C-3007; p.1. 4. Incoronato M, Aiello M, Infante T, Cavaliere C, Grimaldi AM, Mirabelli P et al. Radiogenomic Analysis of Oncological Data: A Technical Survey. Int J Mol Sci. 2017;18(4):805. 5. Karlo CA, Di Paolo PL, Chaim J, Hakimi AA, Ostrounaya I, Russo $P$ et al. Radiogenomics of Clear Cell Renal Cell Carcinoma: Associations between CT Imaging Features and Mutations. Radiology. 2014;270(2):464-71. 6. Mytsyk Yu, Dutka I, Borys Y, Komnatska I, Shatynska-Mytsyk I, Farrooqi A et al. Renal Cell Carcinoma: Applicability of the Apparent Coefficient of the Diffusion-Weighted Estimated by MRI for Improving Their Differential Diagnosis, Histologic Subtyping, and Differentiation Grade, Int Urol Nephrol. 2017;2(49):215-24. 7. Sauk SC, Hsu MS, Margolis DJ, Lu DSK, Rao NP, Belldegrun AS et al. Clear Cell Renal Cell Carcinoma: Multiphasic Multidetector CT Imaging Features Help to Predict Genetic Karyotypes. Radiology. 2011;261(3):854-62. 8. Xie C, Li Y, Li Q, Chen Y, Yao $J$, Yin $G$ et al. Increased Insulin mRNA Binding Protein-3 Expression Correlates with Vascular Enhancement of Renal Cell Carcinoma by Intravenous Contrast-CT and is Associated with Bone Metastasis. J Bone Oncol. 2015;4(3):69-76. 9. Zhu H, Chen H, Lin Z, Shi G, Lin X, Wu Z 
et al. Identifying Molecular Genetic Features and Oncogenic Pathways of Clear Cell Renal Cell Carcinoma Through the Anatomical (PADUA) Scoring System. Oncotarget. 2016;7(9):10006-14. 10. Znaor A, Lortet-Tieulent J, Laversanne M, Jemal A, Bray $F$. International Variations and Trends in Renal Cell Carcinoma Incidence and Mortality. Eur Urol. 2015;67(3):519-30.

Стаття надійшла до редколегії 14.11.2017

\title{
RESEARCH ARTICLES
}

\section{Radiogenomics of Renal Cell Carcinoma: Our Clinical Experience}

\author{
Yu.O. MYTSYK, Y.B. BORYS, V.E. DOSENKO, I.V. DATZ, Y.P. DIYCHUK, \\ V.V. KOWALSKYY, S.M. PASICHNYK, V.M. MATSKEVYCH \\ Danylo Halytskyi Lviv National Medical University, Department of Urology
}

Renal cell carcinoma (RCC) is relatively common pathology that is found roughly in $3 \%$ of all cases of malignant neoplasia in adults and approximately in $90 \%$ of malignant tumors arising because of a kidney. Associations between imaging features and genomic landscape of RCC have been recently investigated in order to characterize better tumor diagnosting more precisely, staging and establishing more accurate prognosis comparing to classic histopathologic approach. Such integration of imaging and molecular biomarkers has led to novel concept of "radiogenomics". In our previous work we have already described usefulness of expression of mi-R-15a measured in urine during RCC diagnostics. Moreover, high miR-15a expression values have been significantly associated with poor survival rates in patients with RCC.

The purpose. The goal of the study is investigation of the associations between cross-sectional imaging features of RCC and urine expression levels of miR-15a.

Materials and methods. 52 adult patients with RCC according to clinical and imaging data have been engaged into study. In all patients' multiphase CT or MRI imaging with contrast enhancement has been performed prior to surgical treatment using standard abdominal protocols. Urine collecting and miR-15a expression measuring has been performed using quantitative polymerase chain reaction. Associations between miR-15a expression and such RCC imaging features as necrosis, renal vein invasion, presence of intratumoral calcifications, definition of tumor margin and architecture, presence of collecting system invasion, intratumoral hypervascularity, homogeneous or nodular tumor enhancement pattern on nephrographic phase images have been assessed. All patients have been treated surgically with the following pathologic analysis.

Results. RCC cases have been classified concordantly to AJCC cancer staging manual: T1aN0M0 ( $\mathrm{n}=13,25,0 \%$ ), T1bN0M0 ( $=15,28,85 \%$ ), T2aN0M0 ( $=12,23,08 \%)$, T2bN0M0 $(\mathrm{n}=5,9,62 \%)$, T3aN0M0 ( $=4,7,69 \%)$, T3aN1M0 $(\mathrm{n}=3,5,77 \%)$. RCCs have been classified according to histologic subtypes - clear cell RCC $(n=22)$, papillary RCC $(n=16)$, chromophobe RCC $(n=14)$. Simplified two-tiered Fuhrman grading system has been used, in which grades I and II (low grade, $\mathrm{n}=12$ ) and grades III and IV (high grade, $\mathrm{n}=10$ ) have been combined. The expression values of miR-15a in urine of patients with RCC have varied from 91,35 to 5,52 relative fluorescence units (RFU), mean $-54,58 \pm 37,76$ RFU. High expression levels of miR$15 \mathrm{a}(>25 \mathrm{RFU})$ in patients with RCC have been associated with necrosis $(\mathrm{p}<0,05)$, ill-defined margins of the lesion $(p<0,05)$ and intratumoral hypervascularity $(p<0,01)$. Lower miR-15a expression levels $(<25 \mathrm{RFU})$ have been associated with imaging evidence of renal vein $(p<0,05)$ and collecting system $(p<0,05)$ invasion, nodular tumor enhancement pattern $(p<0,05)$ and multicystic tumor architecture $(p<0,05)$. There has been no significant association between miR$15 a$ expression and presence of intratumoral calcifications on cross-sectional images $(p>0,05)$.

Conclusions. Radiogenomic analysis may provide valuable information for predicting of emiR-15a expression levels in urine of patients with RCC. In clinical conditions under which there is no possibility to perform genetic assay, imaging features of RCC can be used as surrogates of miR-15a expression to perform prognostication of disease biologic behavior.

Key words: renal cell carcinoma, radiogenomics, microRNA, imaging, biomarker. 